نقش الكتروانعقاد و لختهسازى تكميلى در كاهش اكسيرُنخواهى شيميايى مواد شوينده فاضلاب بهمنظور مصرف در آبيارى فضاى سبز

\author{
هستى هاشمىنزاد"، محبوبه سيدبرزانى، كهربا جيرانى و امير تائبى'

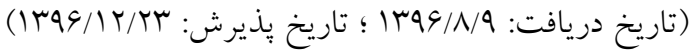

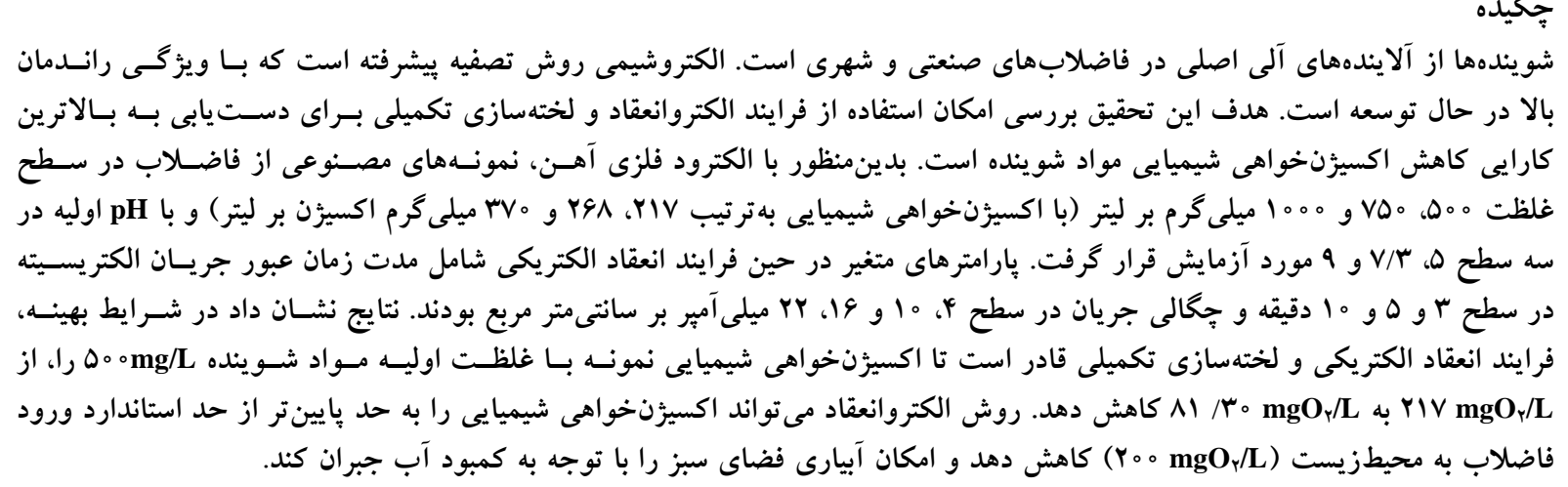

وازههاى كليدى: مواد شوينده، انعقاد الكتريكى، اكسيرنخواهى شيميايى، فاضلاب، آلايندهاى آلى، لختهسازى تكميلى 
همكاران با مطالعه روش الكتروانعقاد و شناورسـازى الكتريكى روى بِاب مصنوعى رختشويى حساوى شـوينده بـا استفاده از

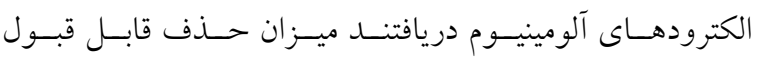

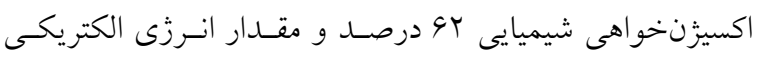

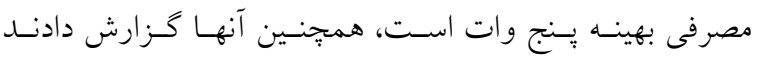

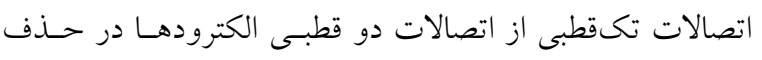
مواد شوينده مؤثرتر است (V) (V)

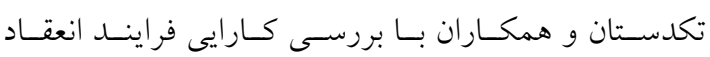

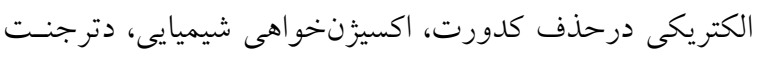

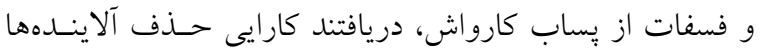

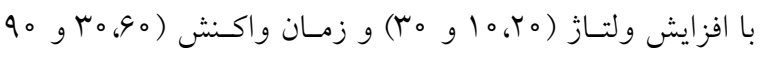

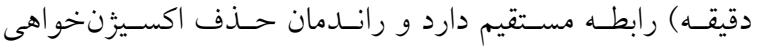
شيميايى در pH اسيدى با ولتاز مبا و زمان واكنش يا زمان مانـــ

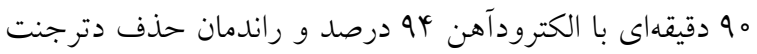

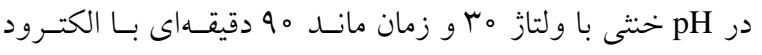
آهن بو درصد است. همجنين فرايند الكترو انعقاد مىتواند يـك روش اقتصادى براى تصفيه بِاب كارواشها يِشنهاد شود (N). شاه منصورى و روشنى با بررسى فراينــ انعقـاد شسيميايى

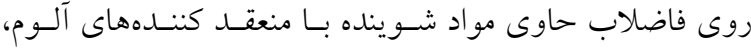

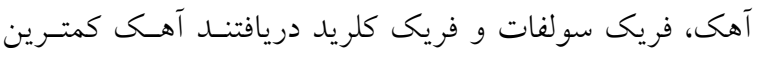

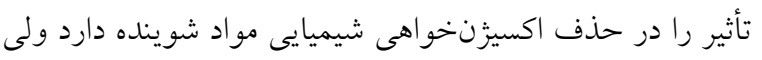

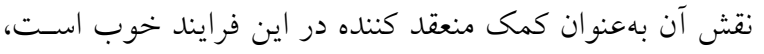
همجينين كزارش دادند قابليت حذف اكسيزنخ اهنى شسيميايى مواد شوينده توسط فريك سولفات و فريك كلريد در فاضـلاب

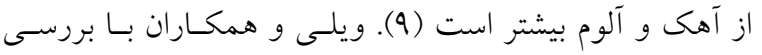
تصفيه شسيرابه زبالـهاى شـهرى بهوسـيله روش الكتروشسيمى

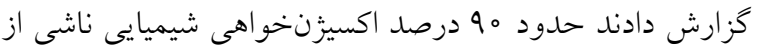

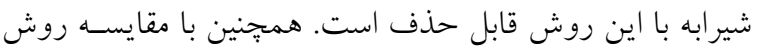

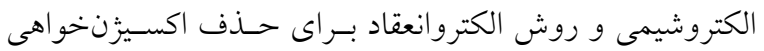
شيميايى شير ابه دريافتند روش الكتروانعقاد با استفاده از الكترود

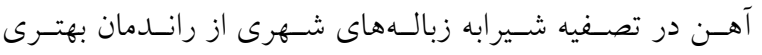

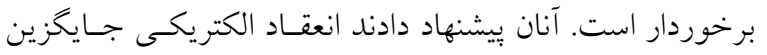

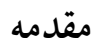
كسترش بيش از حد توليد و مصرف مواد شوينده سبب افزايش يتانسيل آلودخى آبهاى قابل دسترس انسان شــده اسـت. مـواد

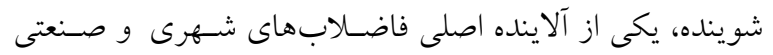

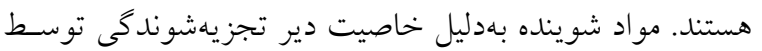
عوامـل زيسـتى موجـب تهليـــ جـــى محيطزيسـت و اثـرات مخرب بيولوزيكى بر جانداران شدهاند. اين مواد همجنين باعث

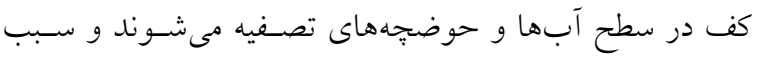

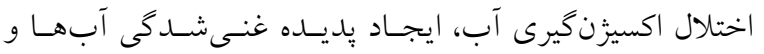

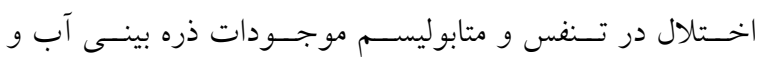

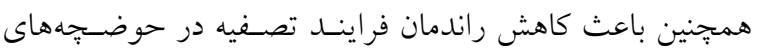

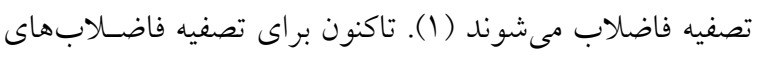

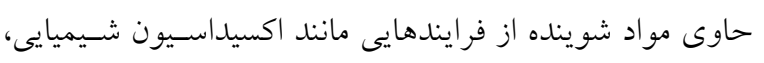

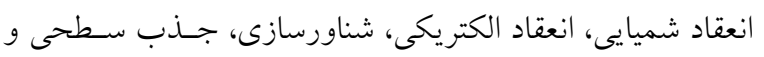
روشهاى بيولوزيكى استفاده شده است (Y). در سالهاى اخيـر

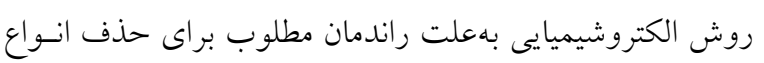

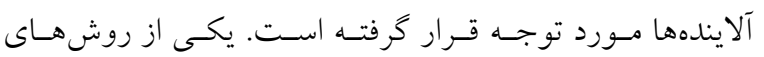

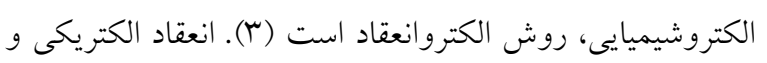

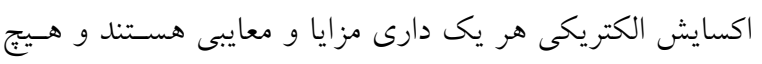

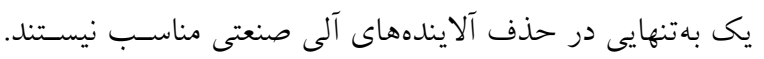

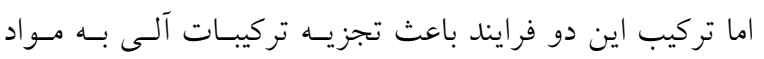

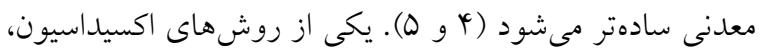

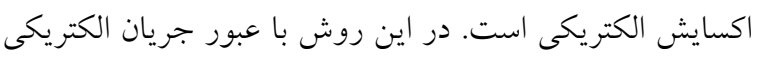
به الكترود فلز مناسب، در سلول الكتريكسى اكسـيدكننده توليـد

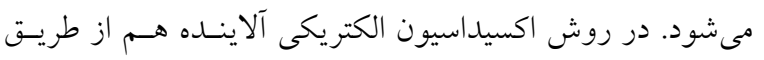

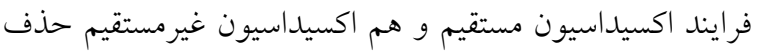

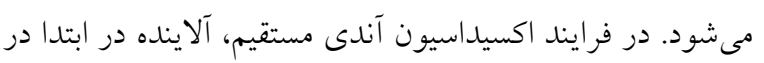

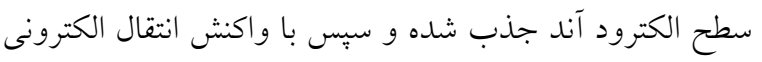
آند، تخريب مىشود. در فرايند اكسيداسيون غيرمستقيم، اكسيد وكيد

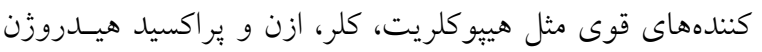

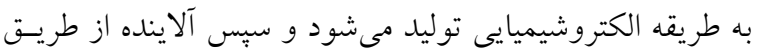

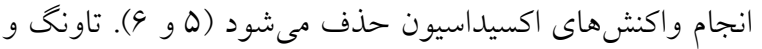


نقش الكتروانعقاد و لختهسازى تكميلى در كاهش اكسيزنخواهى شيميايى ...

جدول ا. مشخصات دستخاههاى مورد استفاده در آزمايشها

\begin{tabular}{|c|c|c|c|}
\hline توضيحات & 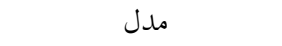 & كارخانه سازنده & نام وسيله \\
\hline ا & MP-6003, 0-4 A, $60 \mathrm{~V}$ & MEGATEK & مبدل جريان برق \\
\hline با دقت |ه0ـ/0 كرم & - & ELE-Sartorious & ترازوى ديجيتال \\
\hline $0 / 01$ & 3045 Ion Analyzer & ElE International & يى'ج متر \\
\hline $\operatorname{rpm} 1 \circ \circ-\wedge \circ \circ$ & MR 3000 & Heidolph & همزن مغناطيسى \\
\hline شش پِدالى با قاشقى مستطيلى & - & Phipps \& Bird & جارتست \\
\hline- & D3006 & Labortechnic & دستخاه توليد آب مقطر \\
\hline- & - & Hach & راكتور COD \\
\hline $0 / 001$ & $\mathrm{DR} / 2010$ & Hach & اسِكتروفتومتر \\
\hline $0 / 01$ & EC 214 & HANNA & هدايتسنج \\
\hline 10/ & - & HITRAX & زمانسنج \\
\hline
\end{tabular}

نمكسهاى فلـزى، يليمرهــا و يلى الكتروليتهــا بــهنوان منعقـــ كننده، از انحلال صفحات فلـزى بــراى توليـــ و افـزودن مـواد

منعقد كننده به فاضلاب استفاده مىشود. هــدف از ايسـن تحقيـت بررسـى امكــان اسـتفاده از فراينـــ الكتروانعقاد و لختهسازى تكميلى براى دسـتيابى بـه بـالاترين كارايى كاهش اكسيزنخواهى شيميايى مواد شوينده در فاضلاب با الكترود و ولتاز بهينه در مقياس آزمايشخاهى است.

\section{مواد و روشها}

تحقيـق حاضـر در مقيـاس آزمايشـعاه بهصـورت بــايلوت در آزمايشخاه محيطزيست دانشكده عمران دانشخاه صنعتى اصفهان بــهنظور تـأثير جريــان بـرق مسـتقيم روى رانــدمان كـاهش اكسيزّنخواهى شيميايى در نمونه حاوى مواد شوينده انجام شـد

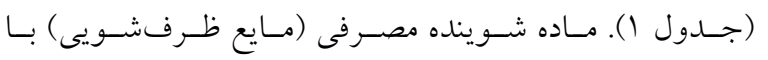
مشخصات تركيبى، آلكيل بنـزن سـولفنات خطى، هيدروكسـيد سديم، دىاتانل آمين، ترىاتانل آمين، كوكونات فتسى اسـيد دى اتانل آميد، اوره، اسانس، آب ديونيزه، متيـل كلروايزوتيـازولينون

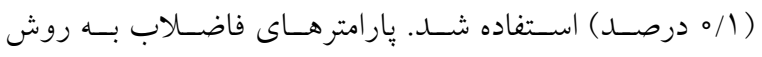
استاندارد آب و فاضـلاب انـدازهيرى شـد (9) (1). روش طـرح

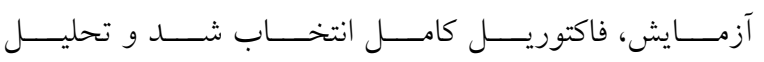

مناسب براى تصفيه شيرابه زبالههاى شهرى است (ام). جانيور و همكاران با مطالعه روى تصفيه يُساب رختشـويى با استفاده از فراينـد الكتروانعقـاد و صـفحات مـوازى الكتـرود

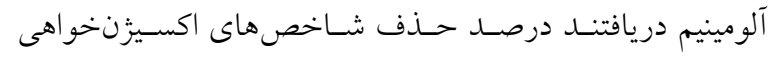

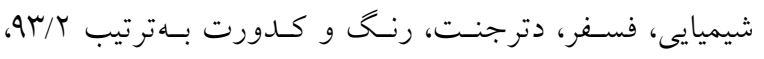

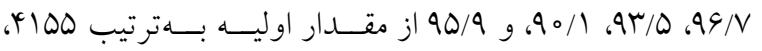

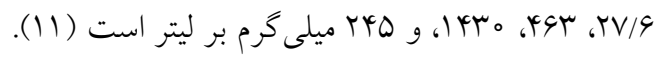

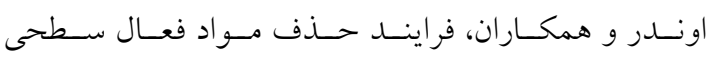
(سورفاكتانتها) را از محلول مدل و نمونه آب آلـوده بـا روش

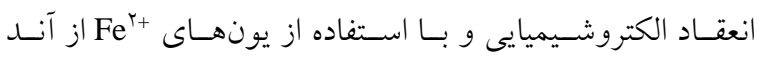
محلول بررسى كردند. آنان گزارش دادند ميزان رانـدمان حـذف لف مواد فعال سطحى با غلظت اوليه ه ا ميلى گرم صد در صد است

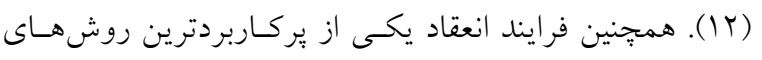
حذف ذرات معلق و كلوئيدى اسـت. فراينـد انعقـاد الكتريكى تاكنون بهعنوان روش مناسب براى تصفيه انواع فاضلاب حاوى مواد روغنى، رنخ، تركيبات حاوى فنل، آرسنيك و غيره توسط يزوهشخران به كار برده شده اسـت (سا و با و و ها). همـانطور كه در مطالعات بيشين نيز بيان شد مىتوان از تكنولوزى انعقـاد الكتريكى بهعنوان روش جايخزين مناسب براى روشهاى انعقاد (شيميايى) استفاده كرد. در ايسن تكنولـوزى بـهـجاى اسـتفاده از 
نشريه علوم آب و خاك (علوم و فنون كشاورزى و منابع طبيعى) / سال بيست و سه / شماره اول / بهار 19r|

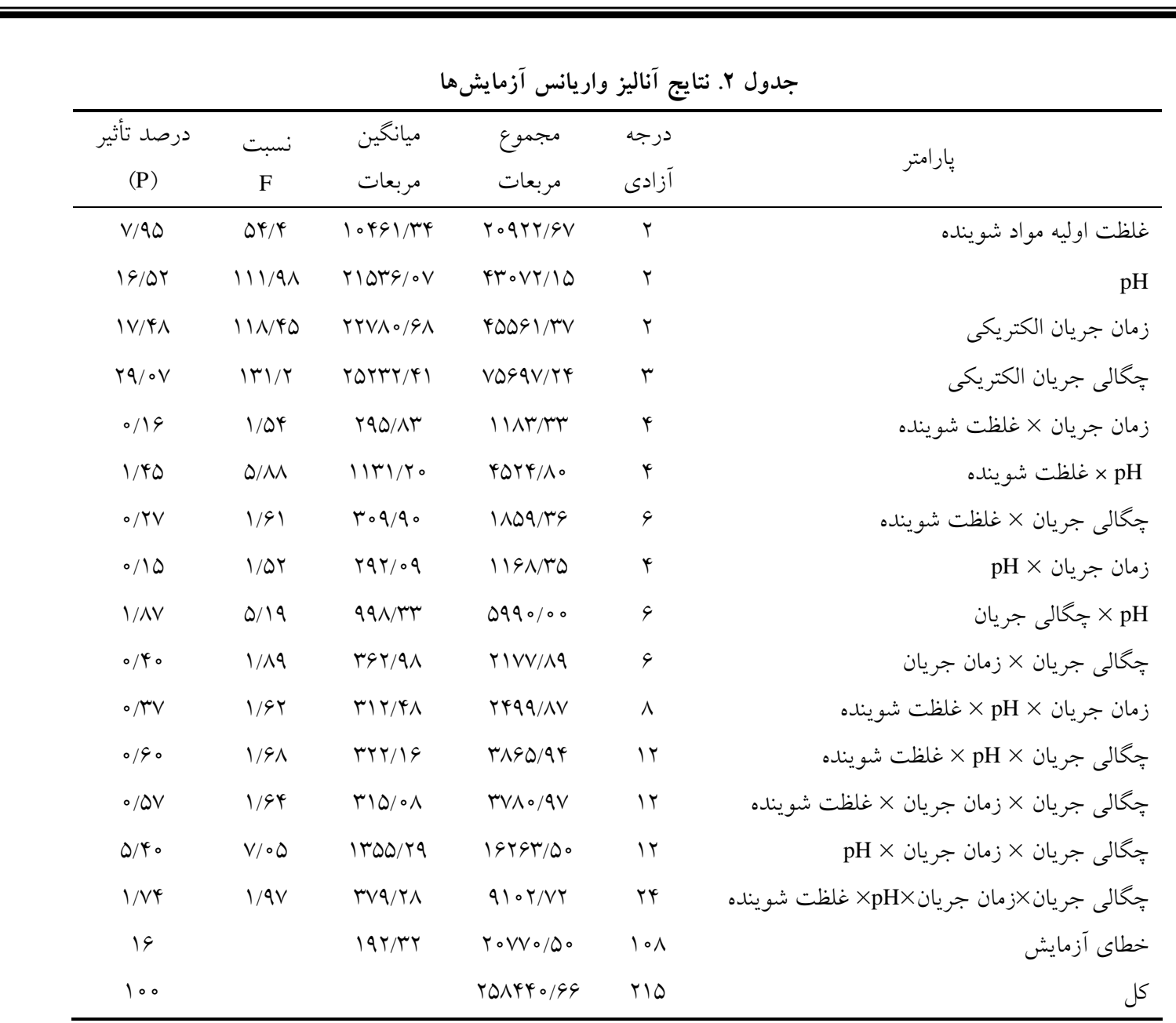

انجام شد و خلاصه نتـايج آن در جـدول (r) نشـان داده شـده است.

اخر نسبت F بيشتر از يك باشد، نشاندهنده بزرگتـر بـودن

واريانس هر عامل نسبت به واريانس خطا است و تـأثير فـاكتور

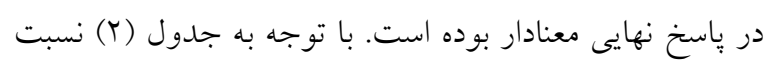

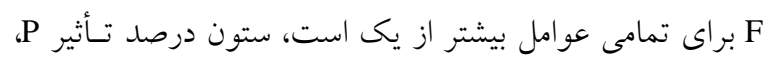

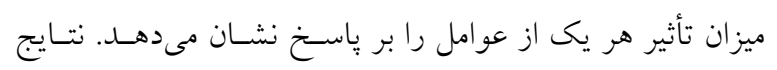
آناليز واريانس نشان داد جِّالى جريان الكتريكى مهمترين عامل

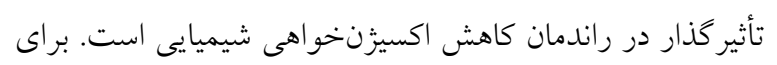

$$
\text { تعيين مقدار راندمان كاهش از رابطه }
$$

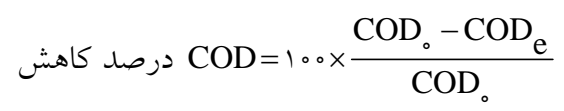

استفاده شد. زمان برقرارى جريان و pH نيز از فاكتورهاى تـأثير
آمارى دادهها در اين تحقيق از نرمافزارهاى Excel و SAS براى

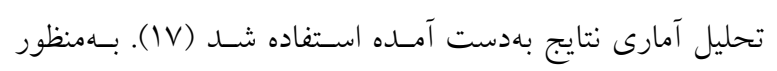

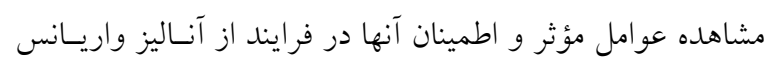

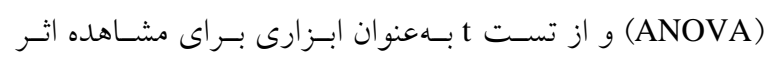
معنىدارى عوامل فرايند بر راندمان كاهش استفاده شد (جــدول ليست تجهيزات مسورد اسـتفاده در جـدول (1) آورده شــه اسـت. الكتـرود آهـن مصـرفى در فراينـــ انعقـاد الكتريكسى بـا

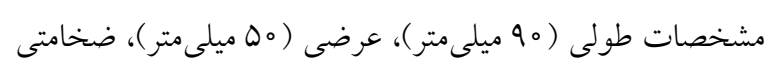

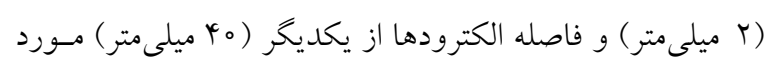

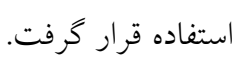
دادههاى بهدست آمده از آزمايشـات در نرمافـزار آمـار وارد شد و يس از بررسى دادهها، آزمون آناليز واريـانس (ANOVA) 

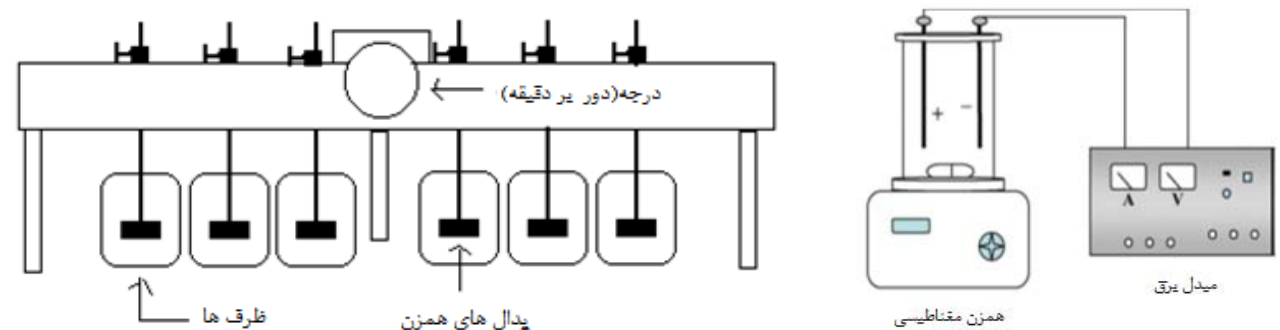

شكل ا. شماتيك ساده از سيستم فرايند انعقاد الكتريكى

\begin{tabular}{|c|c|c|c|c|}
\hline \multicolumn{5}{|c|}{ جدول r. عوامل و سطوح انتخاب شده } \\
\hline & 1000 & $V Q \circ$ & 0.0 & غلظت اوليه مواد شوينده (ميلى كرم بر ليتر) \\
\hline & 9 & $V / r$ & 0 & $\mathrm{pH}$ \\
\hline & 10 & $\Delta$ & r & زمان برقرارى جريان الكتريكى (دقيقه) \\
\hline rt & 19 & 10 & $\varphi$ & جُخالى جريان الكتريكى (ميلى آمير بر سانتىمتر مربع) \\
\hline
\end{tabular}

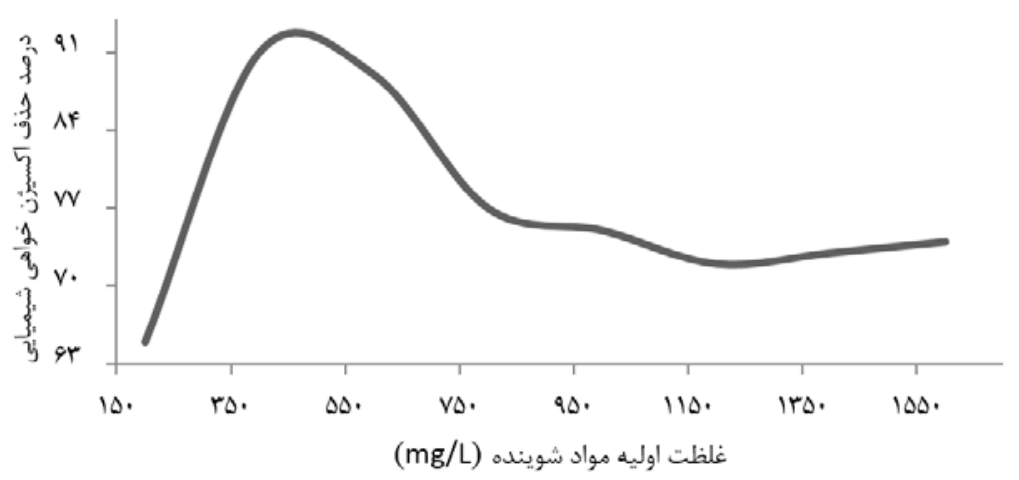

شكل r. تغييرات غلظت اوليه مواد شوينده در درصد حذف اكسيرنخواهى شيميايى در آزمايشهاى اوليه (PH=V/rآمان بران برقرارى جريان

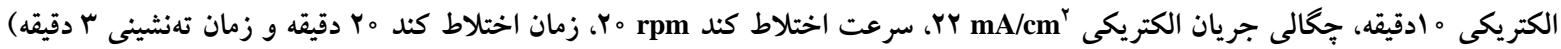

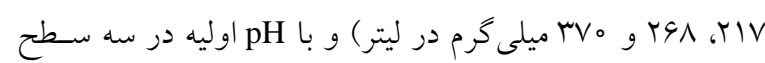

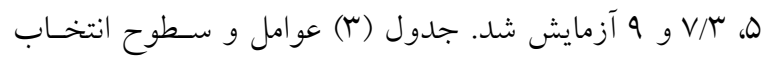

$$
\text { شده را نشان داده است. }
$$

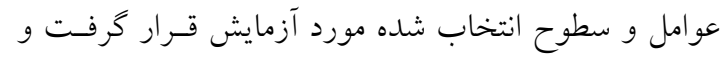
مهمترين عو امل مؤثر در شكل هاى (Y) تا (ه) آورده شده است.

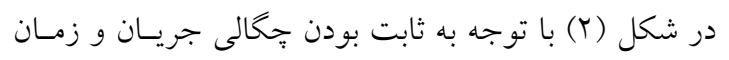

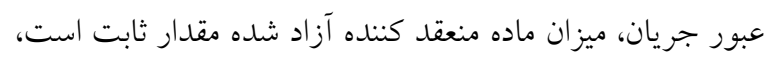

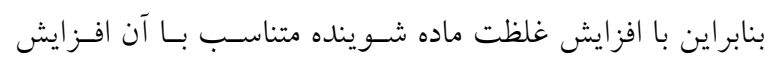

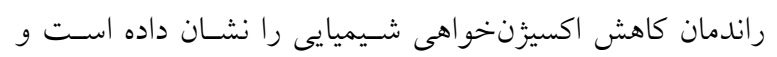

كذار ولى با درصد تأثير كمتـرى هسـتند و غلظــت اوليسه مـواد شوينده كمترين ميزان تأثير را دارا بوده است.

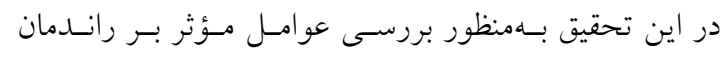

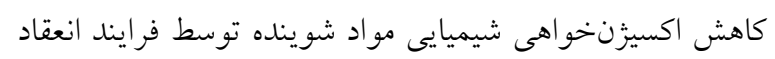

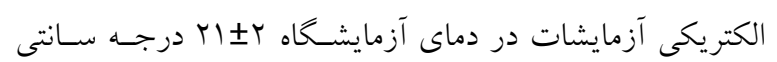

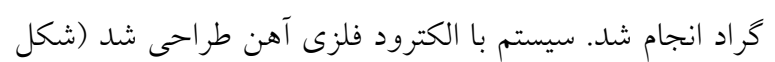

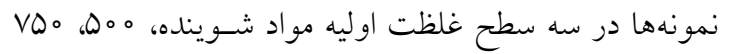

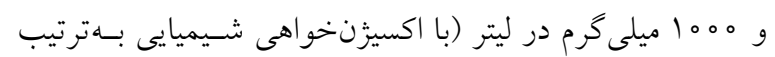


نشريه علوم آب و خاك (علوم و فنون كشاورزى و منابع طبيعى) / سال بيست و سه / شماره اول / بهار 1هـا

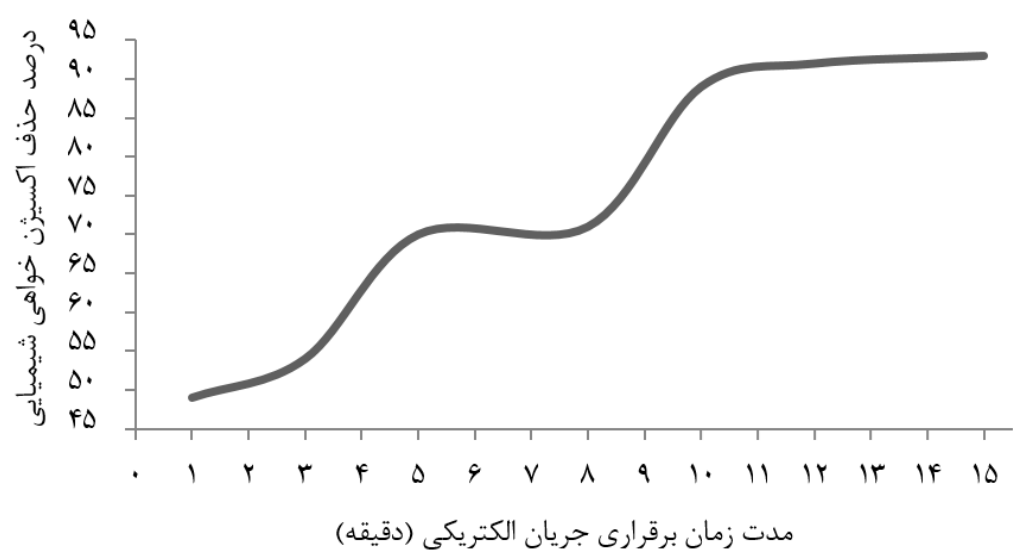

شكل r. مدت زمان عبور جريان الكتريكى در درصد حذف اكسيزنخواهى شيميايى در آزمايشهاى اوليه (غلظت اوليه مواد شوينده

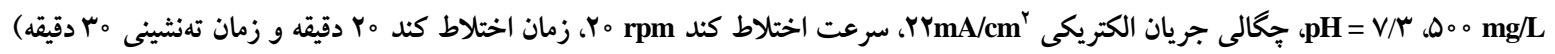

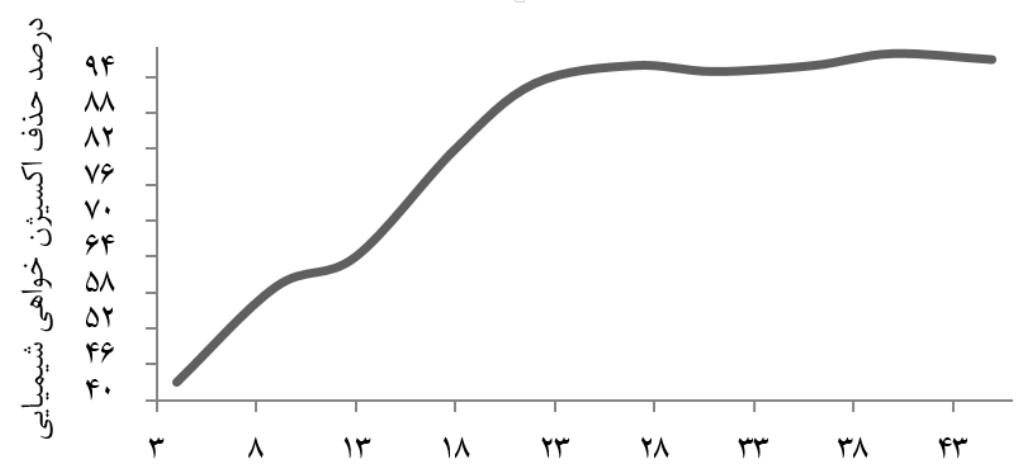

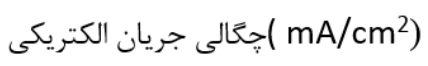

شكل ץ. محدوده جخالى جريان الكتريكى در درصد حذف اكسيزنخواهى شيميايى (غلظت اوليه مواد شوينده

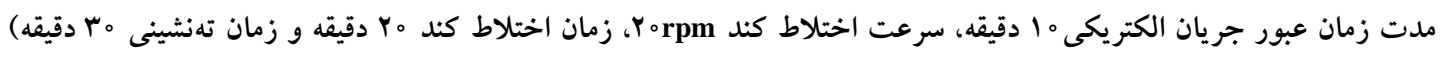

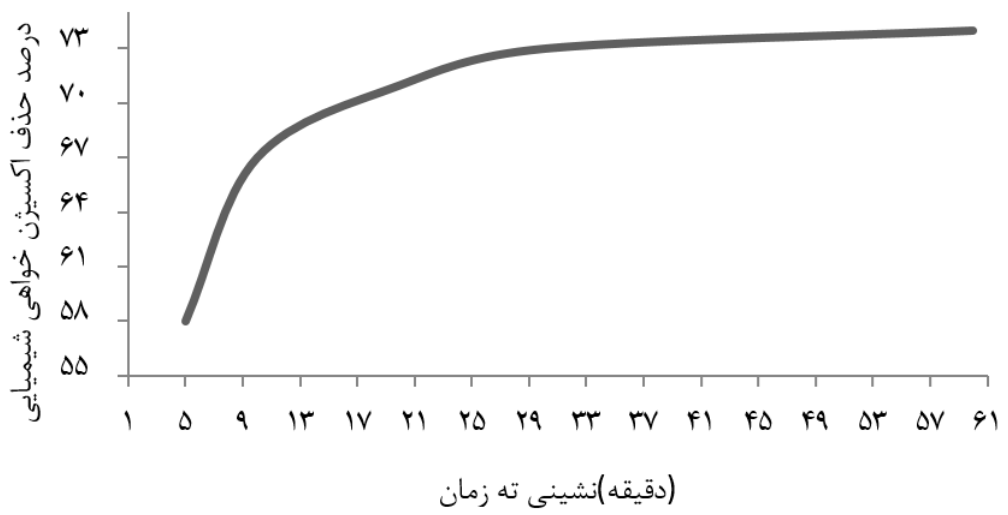

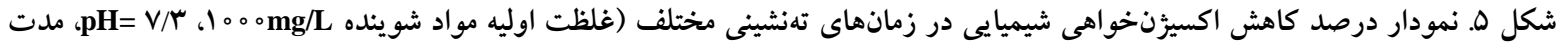

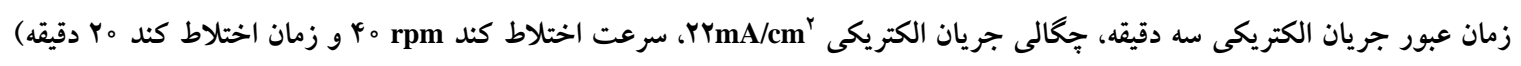


كاهش اكسيزن خواهى از VY به VY درصد افزايش يك درصسىى

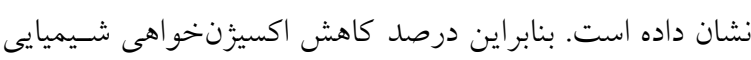
در سرعت اختلاط كند forpm بهعنوان سرعت اختلاط بهينه در

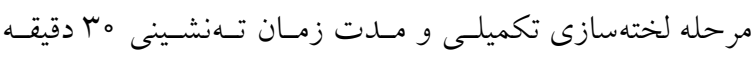
انتخاب شد.

\section{نتايج و بحث}

در اين تحقيق براى بهينه سازى فرايند انعقاد الكتريكى، جهـار عامل غلظت اوليه مواد شوينده، pH، مدت زمـان عبـور جريـان الكتريكى و جُشالى جريان الكتريكى در راكتور ناييوسته بررسى شدند. نتايج نشان داد اثر متقابل غلظت اوليسه مـواد شـوينده در مقابل pH اوليه در كاهش اكسيزنخواهى شيميايى مواد شـوينده از اهميت زيادى برخوردار است. شكل (4) اثــ متقابـل pH بـا غلظت شوينده بــر درصـد كـاهش اكسـيزن إخو اهى شـيميايى را نشان مى دهد. در شـرايط ثابـت pH برابــر V/ در بـين غلظت هــاى مـورد

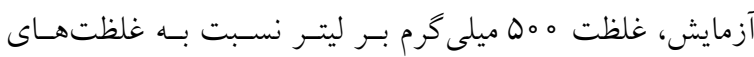
ديخر، بالاترين مقدار درصد كاهش اكسيزئنخواهى شـيميايى را نشان داده است. مىتوان علت اين شرايط را به تشكيل رسـوب

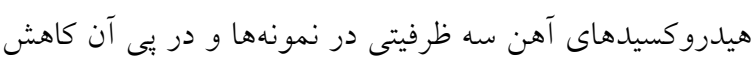
اكسيزّنخواهى شيميايى از نمونههاى وابسته به pH بيان كرد. در

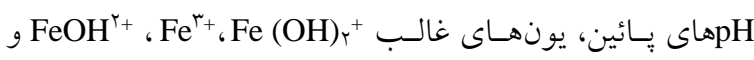

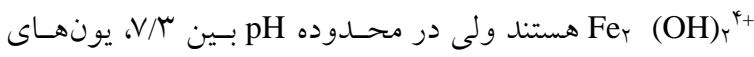
آهـن آب بوشسى شـده و يـون غالـب (s) r(OH) اسـت كـهـ مىتواند يس از انجام نقش خود بهعنوان منعقد كننده، به راحتى رسوب كند و از محيط آبى خارج شود و ايسن موضسوع باعسث افزايش راندمان كاهش مىشود. در هاى بازى كونه غالـب

$$
\text { Fe (OH }{ }^{4-}
$$

همانطور كه در شكل (V) نشان داده شده است بـا افـزايش

درصد كاهش اكسـيزن pH

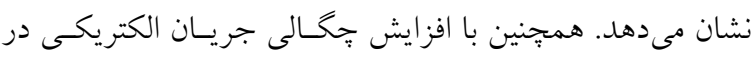

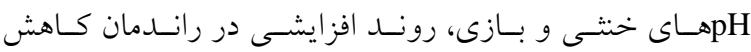

يس از افزايش غلظت شوينده از حدود هـمه ميلى گـرم در ليتــ بهدليل ناكافى بودن جّالى جريـان (دز منعقــ كنتـده توليـدى) راندمان كاهش اكسـيزنخواهى شـيميايى كـاهش يافتـه اسـت. هم:جنين غلظتهاى مورد آزمون نشـان داد غلظـت تا و در اين محدوده غلظـت VD॰mg/L بـهنونو ان شـاخص غلظـت

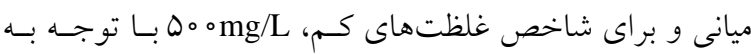
مقدار پِارامتر جّخالى جريان الكتريكى، سرعت اخـتلاط و زمـان تهنشينى انتخاب شده است. شكل (r) نمونهاى از سرى آزمايشات براى بهدسـت آوردن

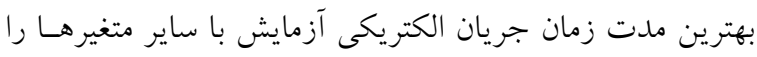
نشان مى دهد. در شكل مذكور غلظت ماده شوينده ثابت و مدت زمان برقراى جريان الكتريكى بهعنوان متغير اسـت، بـا افـزايش

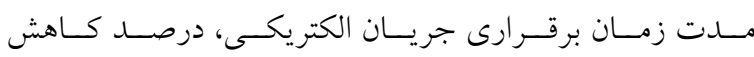
اكسيززنخواهى شيميايى، روند افزايشى را نشان داد. تا جايى كه ديخر افزودن ماده منعقد كننده با توجه به غلظت شـوينده تـأثير

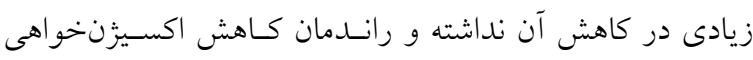
شيميايى تقريباً روند ثابت را نشان داده اسـت. بنـابراين از بـين مدت جريانهاى الكتريكـى مـورد آزمسون، مســت زمـان عبـور جريان الكتريكى • ا دقيقه انتخاب شد.

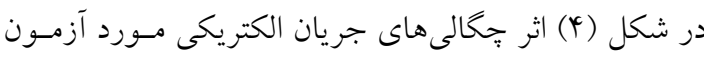
بــر ميـزان حسـف اكسـيزن خـواهى شسيميايى نشـان داده شــده

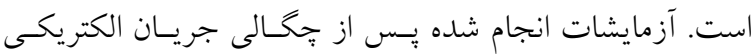
rrmA/cmr نوسان سه تا جهـار درصــ نشـان مىدهــ، لـذا از نظـر صـرفه

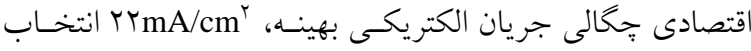
شده است. در شكل (ه) آزمونهاى مدت زمان تهنشينى با ساير عوامل تأثير گذار مورد آزمون قرار گرفته است. شكل نشان مىدهـــــــا افزايش مدت زمان تهنشينى از ه بـهـه دقيقـه، رانـدمان كـاهش

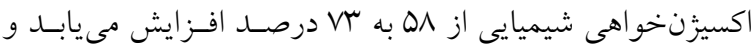

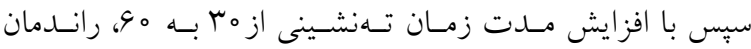




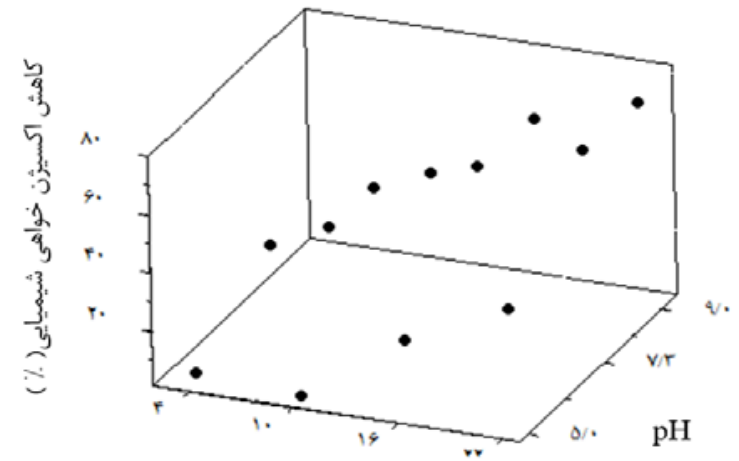

جَّالى جريان الكتريكى(

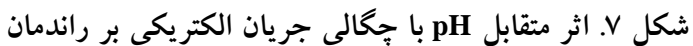

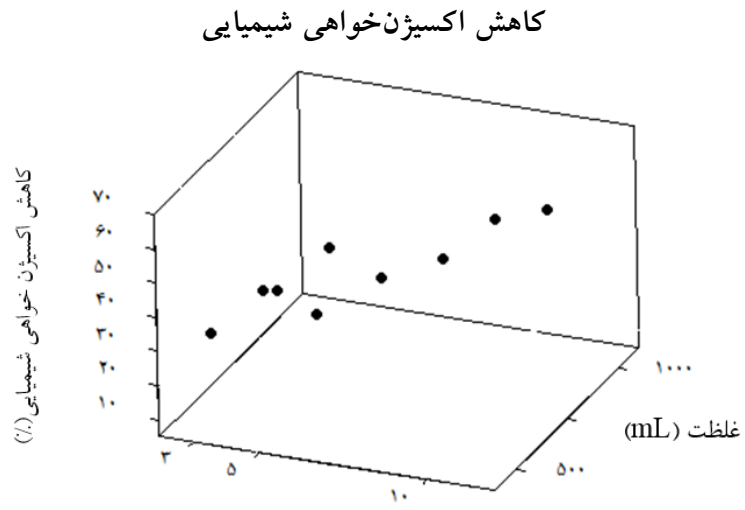

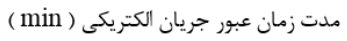

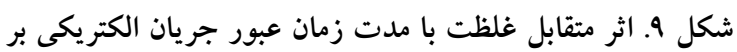

$$
\text { درصد كاهش اكسيزنخواهى شيميايى }
$$

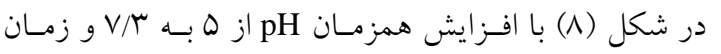
عبور جريان از r به ه درصد، كاهش از ا به ب ه افزايش يافته و با افزايش همزمان pH از م/ به 9 و مد مدت زمان عبور جريان از

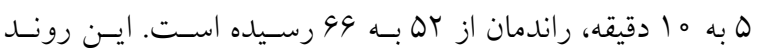
افزايشى همزمان مىتواند بهعلت مدت زمان بيشتر بـراى توليــ ماده منعقد كننده مـؤثر بـر مـاده شـوينده و خــارج شـدن آن از محيط محلول باشد. همــانطور كـه بيشـتر نيـز اشـاره شـد، در هاى بـازى بـهعلت ايجـاد يونهـاى هيدرواكسـيد آهـن در حضور ماده شوينده، درصد كاهش اكسيزنخواهى شسيميايى بـه علت خارج شدن ماده شوينده طى مكانيسم جـاروب كـردن در فرايند انعقاد افزايش يافته است. در شكل (9) با افزايش همزمان غلظت اوليه مواد شوينده از

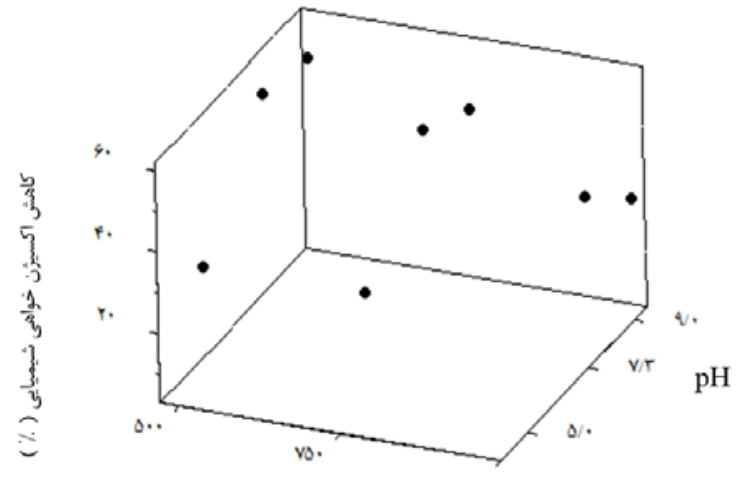

غلظت (ml)

شكل و. اثر متقابل pH با غلظت شوينده بر راندمان كاهش

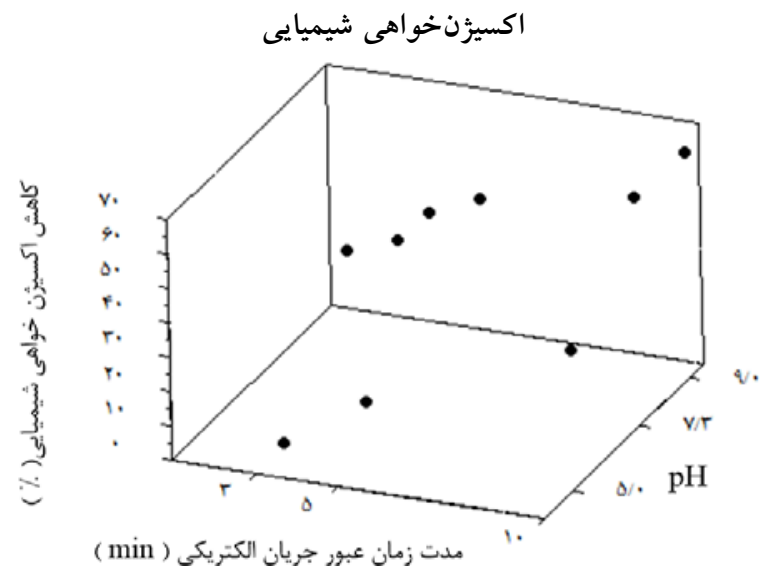

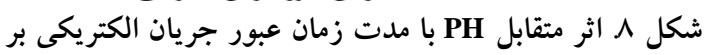
درصد كاهش اكسيزّن خواهى

اكسيزن خواهى شيميايى بهدست آمله است. بـا افـزايش همزمـان

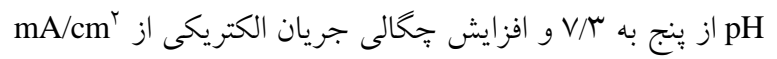

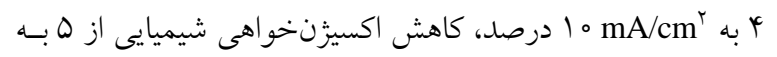

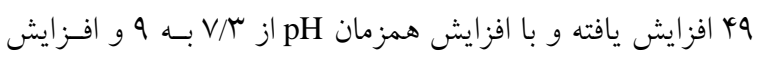

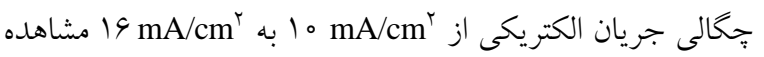

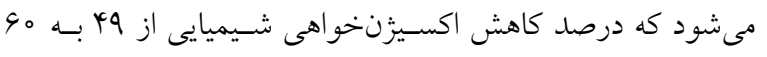
مجدداً افزايش مىيابد. اين اتفاق مىتواند در حضور ماده شـوينده در هاى بازى باشد كه اين ماده با توجه به استـفاده از جريـان الكتريكى و اسـتفاده از الكتـرود آهـن منجــر بـهـ توليـــ يونهـاى هيدرواكسيد آهن شده و مىتوانـد منجـر بـه خـارج شـدن مـاده شوينده بلهوسيله مكانيسم جاروب كـردن در فراينـد انعقـاد و بـــ دنبال آن كاهش اكسيزنخواهى شيميايى محلول شود. 


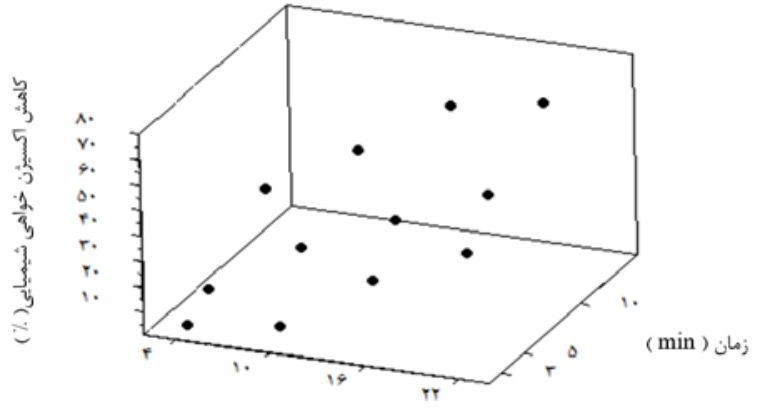

جكالى جريان الكتريكى (mA/

شكل 11. اثر متقابل زمان عبورجريان الكتريكى با جـالى جريكان الكتريكى بر درصد كاهش اكسيزّنواهى شيميايى

بيشتر در اثر افزايش جخَـالى جريـان و احتمــال برخـورد مـواد شوينده بهعلت بالابودن غلظـت مـواد شـوينده باشـد كـه ايسن موضوع منجر به ايجاد كميلكس هاى لختهاى مىشود.

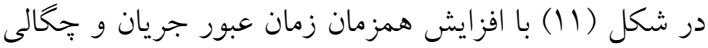
جريان درصد كاهش اكسـيزنخواهى شـيميايى افـزايش مىيابــ. براى مثال با افزايش زمان برقرارى جريان از سه به يــنج دقيقهـ و ج جالى جريان از

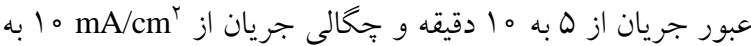
19 mA/cm بهترتيب درصد كاهش اكسيزنخواهى شيميايى از r به اس و از اس به ل ا افزايش يافته اسـت. افـزايش شـيب نمـودار درصد كاهش اكسـيزنخواهى شـيميايى در ايسن مسورد مىتوانــ بهعلت اثر همزمان دو بارامتر مدت زمان عبور جريان الكتريكى و جّالى جريان (كه هر دو با توليد مواد منعقد كنتده رابطـه دارنــد) بر لختهسازى حاصل از ماده شوينده باشد.

\section{تيتيجه كيرى}

درصد كاهش اكسـيزن نخواهى شـيميايى بـا توجسه بـه شـرايط فاضلاب حاصل از ماده شوينده مورد بررسى قرار گرفته است. فرايند انعقاد الكتريكى با الكترود آهن در محدوده مدت زمـان عبور جريـان الكتريكسى از ب تـا ه ا دقيقسه و جخــالى جريـان

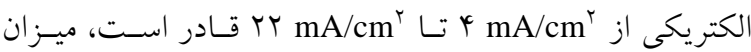
اكسيززنخواهى شيميايى نمونه با غلظـت اوليسه مـواد شـوينده

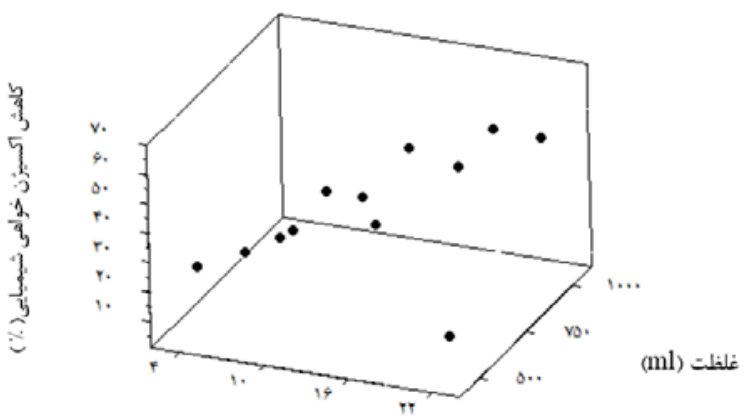

جكالى جريان الكتريكي (mA/cm²

شكل ه ا. اثر متقابل غلظت با جگالى جريان الكتريكى بر راندمان كاهش اكسيرن إخواهى شيميايى

و و افزايش مدت زمـان عبـور جريـان الكتريكى از سه به بــنج دقيقـه، درصــ كـاهش اكسـيزن انهو اهى شيميايى از الب به بل افزايش يافته اسـت. ايسن رونسـ صـعودى مىتواند بهعلت افزايش توليد منعقد كننده بيشتر در اثر افـزايش ملت زمان برقرارى جريـان و احتمـال برخـورد مـواد شـوينده بهعلت افزايش غلظت مواد شوينده باشد كه اين موضوع منجـر به ايجاد كميلكس هـاى لختـهاى مى شـود. بــا افـزايش همزمــان

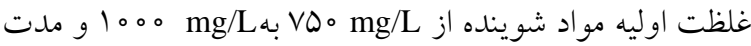
زمان برقرارى جريان الكتريكى از ه به ه ا دقيقه، درصد كاهش

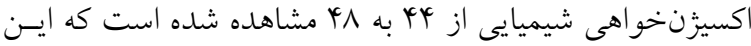
مقدار ناجيز است. شكل (0 ا ) با افزايش همزمان غلظت اوليه مـواد شـوينده از و و افزايش جخالى جريان الكتريكى از

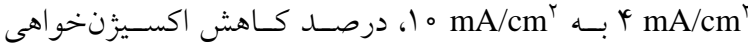

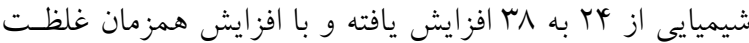

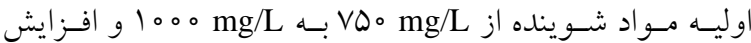
جֶحالى جريان الكتريكى از

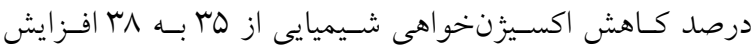
يافته است. به همين ترتيب با افزايش جّالى جريان الكتريكى و مقـــار غلظــت مــاده شــوينده، رونـــــ صــودى كــاهش اكسيززنخواهى شيميايى (حداكثر هو درصد) را نشان داده است. اين روند صعودى مىتواند بهعلت افزايش توليــ منعقــ كنـــده 


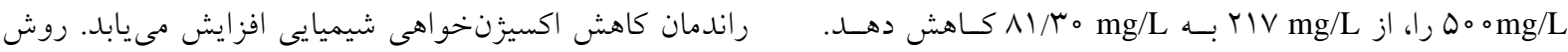

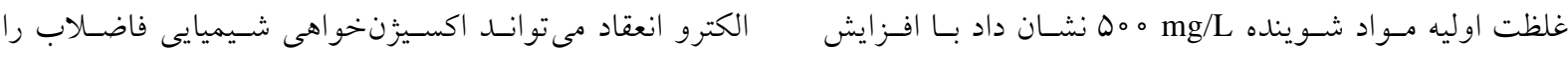

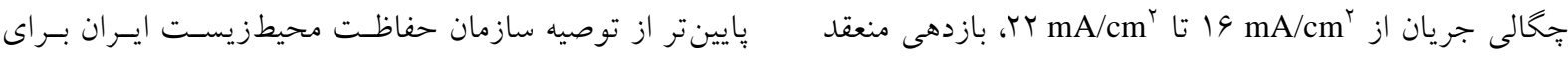

$$
\begin{aligned}
& \text { كننده كاهش مى يابد. در فرايند انعقاد الكتريكى، pH مناسـب، ورود فاضلاب به آبهاى سطحى (Y。mgO/ll) كاهش دهد } \\
& \text { معادل س V/r pH طبيعى تيمارها) است. با افزايش مـدت زمـان و امكان استفاده مجدد از فاضلاب بهداشتى براى فضاى سـبز }
\end{aligned}
$$

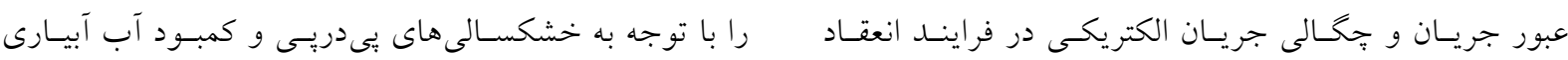

$$
\begin{aligned}
& \text { الكتريكى (كه به معناى توليد بيشتر ماده منعقــد كنتـده اسـت) ايجاد كند. }
\end{aligned}
$$

منابع مورد استفاده

1. Javid, A. H., S. A. Mirbagheri and M. Pourtalari. 2006. Detergent removal from wastewater of automobile industry and its standardization. Journal of Environmental Science and Technology 3(8): 29-34.

2. Aboulhassan, M. A., S. Souabi, A. Yaacoubi and M. Baudu. 2006. Removal of surfactant from industrial wastewaters by coagulation flocculation process. International Journal of Environmental Science and Technology 3(4): 327-332.

3. Zhao, X., G. B. Zha and J. Liu. 2010. Removal of arsenite by simultaneous electro-oxidation and electrocoagulation. Journal of Hazardous Materials 184: 472-476.

4. Linares,I , C. Barrera , P. Bilyeu and E. Campos. 2010. A combined electrocoagulation electro oxidation treatment for industrial wastewater. Journal of Hazardous Materials 175: 688-694.

5. Mancha, C. 2002. Combined electrocoagulation and assisted electrochemical coagulation of aqueous. Journal of Applied Electrochemistry 32: 1241- 1246.

6. Ashtoukhy, E. S. Z. E. I. and N. K. Amin. 2009. Removal of acid green dye 50 from wastewater by anodic oxidation and electrocoagulation-A comparative study. Journal of Hazardous Materials179: 113-119.

7. Tawang, C., W. Lung chou and Y. Ming kuo. 2009. Removal of COD from laundry wastewater by electrocoagulation/electro flotation. Journal of Hazardous Materials 164: 81-86.

8. Takdastan, A., M. Ahmadi moghadam, M. Rahimi. 2010. Study on the removal of COD from petrochemicals wastewater by electrocoagulation with aluminum and iron electrodes. In: Proceeding of the Conference and Exhibition on Environmental Engineering, Tehran.

9. Shahmansori, M. and B. Roshani. 2005. Investigating wastewater treatment of detergent industries by coagulation process at laboratory scale. Journal of Shahid Sadoughi University of Medical Sciences and Health Services of Yazd 1(13): 62-65.

10. Veli, S., T. Ozturk and A. Dimoglo. 2008. Treatment of municipal solid wastes leachate by means of chemical and electro-coagulation. Separation and purification Technology 61: 82-88.

11. Janpoor, F., A. Torabian and V. Khatibikamal. 2011. Treatment of laundry waste-water by electrocoagulation”. Journal of Chemical Technology and Biotechnology 86: 1113-1120.

12. Onder, E., A. Savas, K. Ülker and B. Ögü tveren. 2007. An alternative method for the removal of surfactants from waste water: electrochemical coagulation. Separation and Purification Technology 52: 527-532.

13. Chen, X., G. Chen, P. L. Yue. 2000. Separation of pollutants from restaurant wastewater by electrocoagulation. Separation and Purification Technology 19(1): 65-765.

14. Kobya, M., O. Taner Can, M. Bayramoglu. 2003. Treatment of textile wastewaters by electrocoagulation using iron and aluminum electrodes. Journal of Hazardous Materials 100(1): 163-178.

15. Sanchez-Calvo, L., J. P. Leclerc, G. Tanguy and M. C. Cames. 2003. An electrocoagulation unit for the purification of soluble oil wastes of high COD. Environmental Progress 22(1): 57-65

16. Rice E. W., R. B. Baird and A. D. Eaton. 2017. Standard Methods for the Examination of Water and Wastewater”, $23^{\text {th }}$ Ed., American public Health Association, Washington DC.

17. Dehghani, M. 2007. A summary of the design and analysis of the experiments”, $1^{\text {st }}$ Ed, pelk publication, Tehran.

18. Yousuf, M., A. Mollah, R. Schennac, J. R. Parga and D. Cocke. 2001. Electrocoagulation (EC). Science and Applications (84): 29-41. 


\title{
The Role of Electrocoagulation and Complementary Flocculation in Reducing the COD of Wastewater Detergents for Irrigation Use
}

\author{
H. Hasheminejad*, M. Sayedbarzin K. Jeirany and A. Taebi ${ }^{1}$
}

(Received: October 31-2017 ; Accepted: March 14-2018)

\begin{abstract}
Detergents are the main organic pollutants in the industrial and domestic wastewater. Electro-chemistry methods are advanced purification methods developed with high efficiency features. The goal of this study was to investigate the possibility of using electrocoagulation and the complementary flocculation process to achieve the highest removal efficiency of the detergent COD. So, with iron electrode, synthetic samples at the concentrations of 500, 750 and 1000 mg/l (with COD of 217, 268 and $370 \mathrm{mg} / \mathrm{l}$, respectively) and with the initial pH levels of 5, 7.3 and 9 were tested. Variable parameters during the electrocoagulation process included the current duration at 3, 5 and 10 minutes, and the current density was at $4,10,16$ and $22 \mathrm{~mA} / \mathrm{cm}^{2}$. The primary results showed that in the optimum conditions, the coagulation process and complementary flocculation could reduce the sample's COD with an initial concentration of detergent $(500 \mathrm{mg} / \mathrm{l})$ from $217 \mathrm{mgO}_{2} / \mathrm{l}$ to $81.30 \mathrm{mgO}_{2} / \mathrm{l}$. The electrocoagulation method could reduce the chemical oxygen demand to below the standard limit of environmental discharge $\left(200 \mathrm{mgO}_{2} / \mathrm{l}\right)$ and compensate for the possibility of the irrigation of green spaces due to water shortages.
\end{abstract}

Keywords: Detergent, Electrical coagulation, Chemical oxygen demand, Sewage, Organic pollutants, Complementary flocculation

1. Department of Civil Engineering, Isfahan University of Technology, Isfahan, Iran.

*: Corresponding Author, Email: hhasheminejad@cc.iut.ac.ir 